\title{
Occurrence and Health Risk of Heavy Metals and Microorganisms in Wastewater Collected from selected Eateries in Lekki, Lagos, Nigeria
}

\author{
Yahaya T. ${ }^{*}$, Abdulganiyu Y. ${ }^{2}$, Alkali M. ${ }^{3}$, Obi C. ${ }^{4}$, Ukpere M. ${ }^{5}$, Ayodeji S. O. ${ }^{1}$ \\ and Ahmadu A. I. ${ }^{2}$ \\ ${ }^{1}$ Department of Biological Sciences, Federal University Birnin Kebbi, PMB 1157, Kebbi State, Nigeria \\ ${ }^{2}$ Department of Geology, Federal University Birnin Kebbi, Nigeria \\ ${ }^{3}$ Department of Pure and Industrial Chemistry, Federal University Birnin Kebbi, Nigeria \\ ${ }^{4}$ Department of Microbiology, Federal University Birnin Kebbi, Nigeria \\ ${ }^{5}$ Department of Environmental Science and Resource Management, National Open University of Nigeria, Lagos \\ Corresponding Author: *yahayatajudeen@gmail.com, yahaya.tajudeen@fubk.edu.ng
}

https://doi.org/10.36263/nijest.2022.01.0316

\begin{abstract}
The number of eateries is growing around the world because they provide jobs and food to urban people who do not have time to cook. However, there are concerns that eatery wastewater may contain hazardous compounds and microorganisms. In view of the above, this study determined the chemical characteristics, heavy metal concentrations, and microbiological loads of wastewater collected from three eateries in Lekki, Lagos, Nigeria. The human exposure to heavy metals via oral and dermal contact, as well as the hazard quotient of daily exposure to these heavy metals, was also calculated. The chemical characterization revealed that nitrate, ammonia, and phosphate levels in all of the wastewater samples were above the limits of the Federal Environmental Protection Agency, while sulphate levels were normal. Copper, lead, cadmium, nickel, and chromium levels were within the permissible levels, but zinc was above the limits in the three eateries. The average daily oral and dermal exposure to heavy metals was normal, while the hazard quotient of daily dermal exposure to zinc and chromium in the three eateries was abnormal (> 1). In all of the eateries, bacterial and fungal levels were above permitted limits, but no coliforms were found. The results imply that the wastewater from the three eateries are hazardous and could pose environmental and health hazards. It is recommended that eatery owners treat wastewater before releasing it into the environment.
\end{abstract}

Keywords: Ammonia, Average daily Ingestions, Bacteria, Eateries, Lead, Wastewater

\subsection{Introduction}

Studies have linked increasing heavy metal exposure and microbial infection to the rising prevalence of diseases worldwide (Wu et al., 2019; Yahaya et al., 2020a). More than 200 diseases are caused by pathogenic bacteria and chemicals found in food alone, ranging from diarrhea to cancer (WHO, 2020). Biogeochemical cycles, soil fertility, decomposition of dead plants and animals, biodegradation of organic chemicals, and health promotion all require microorganisms (Felicita and Marija, 2017; Macro, 2020). At certain levels, however, some bacteria, fungi, protozoa, and viruses can cause diseases (Steffan et al., 2018). Heavy metal has no precise definition; however it is broadly described as any element having a high molecular weight and a density five times that of water (Yahaya et al., 2020b). The most common heavy metals are lead (Pb), cadmium (Cd), arsenic (As), mercury $(\mathrm{Hg})$, manganese $(\mathrm{Mn})$, nickel $(\mathrm{Ni})$, zinc $(\mathrm{Zn})$, chromium $(\mathrm{Cr})$, cobalt $(\mathrm{Co})$, copper $(\mathrm{Cu})$, molybdenum (Mo), and antimony (Sb) (Bhargava et al., 2017). In small quantities, heavy metals perform biological functions in the body (Yahaya et al., 2019). However, at certain concentrations, 
they can cause health problems such as respiratory, genetic, and hematological diseases, as well as damage to the skin, eyes, and brain (Yahaya et al., 2011; Yahaya et al, 2012).

Sources of heavy metals in the environment include soil erosion, weathering, agrochemicals, mining, and wastes (liquid, solid and gas) from homes and industries (Chen et al., 2017; Du et al., 2020). Microorganisms, on the other hand, may be found almost anywhere and are the most common type of life on the earth (Felicita and Marija, 2017). Almost every industry releases harmful chemicals or microorganisms into the environment. Eateries, in particular, release significant amounts of microorganisms and chemical-laden wastewater into the environment as a result of increased urbanization (Khedkar and Singh, 2018). Food scraps, oils, soaps, plastic packaging, and human wastes, among other things, are found in eatery wastes (Turek et al., 2019; Tyta, 2019). These wastes end up in water bodies, posing a threat to drinking and domestic water quality (Wang et al., 2020; Jingxi et al., 2020). It can also compromise the aquatic ecosystem by raising the water's organic loads, resulting in lower dissolved oxygen levels and nutrient overload (Okoh et al., 2007). This necessitates safety assessment of wastewaters from various eateries before they are dumped into the environment.

In Lagos, Nigeria, the number of eateries is rapidly expanding because they provide jobs and meals to urban residents who do not have time to cook. However, a review of the literature revealed that the safety of wastes generated by eateries in the city has not been assessed. The safety assessment of the wastes becomes necessary to ensure a sustainable environment in which eateries can expand without jeopardizing people's health or the environment. As a result, this study evaluated the chemical characteristics, heavy metal concentrations, and microbial loads of wastewater from selected eateries in Lekki, Lagos, Nigeria, as well as the health hazards they pose.

\subsection{Methodology}

\subsection{Description of the study area}

This study was conducted in Lekki area of Lagos, Nigeria (Figure 1). Lekki is located between the longitudes of $4^{\circ} 00^{\prime} \mathrm{E}$ and $4^{\circ} 15^{\prime} \mathrm{E}$, as well as the latitudes of $6^{\circ} 22^{\prime} \mathrm{N}$ and $6^{\circ} 37^{\prime} \mathrm{N}$ (Opadokun et al., 2015). Lagos has a total area of $3577 \mathrm{~km}^{2}$, including water bodies (Aniyikaye et al., 2019). On the north and east, Lagos is bordered by Ogun State, while on the south and west, it is bordered by the Atlantic Ocean and the Republic of Benin, respectively. Lagos is predominantly covered in tropical swamp forest, which includes both freshwater and mangrove swamp forests (Aniyikaye et al., 2019). The wet season, which begins in April and ends in October, and the dry season, which begins in November and ends in March, are the two major seasons in the state. The daily temperature averages between $26{ }^{\circ} \mathrm{C}$ and $30{ }^{\circ} \mathrm{C}$. Lagos is estimated to have a population of around 17.5 million people (Aniyikaye et al., 2019). Lekki is one of Lagos' most densely populated areas, populated largely by the wealthy and home to a number of eateries. 


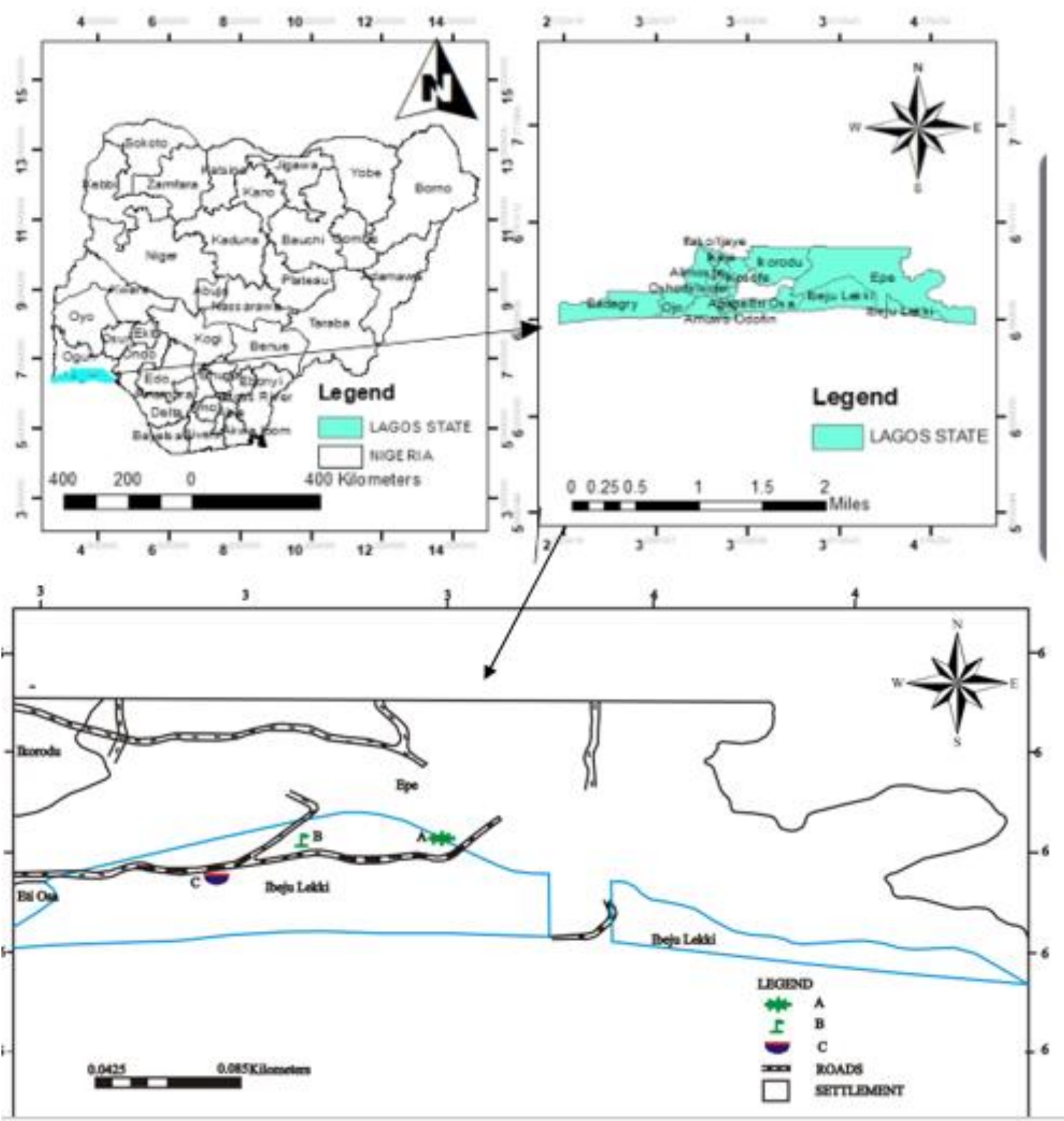

Figure 1: Map of Lagos showing the study areas

\subsection{Sample collection}

Between February and April 2021, wastewater samples were collected every other week in presterilized, clean, and dry polyethylene bottles from three eateries in Lekki, Lagos. The bottles were sealed tightly and transported to the laboratory, where they were refrigerated at about $4{ }^{\circ} \mathrm{C}$.

\subsection{Quality control}

Analytical reagent grade chemicals were employed throughout. All preparations and dilutions were done with distilled water. For digestion, $\mathrm{HNO}_{3}(69 \%)$ and $\mathrm{HCl}(98 \%)$ were used. Stock standard solutions of $1000 \mathrm{ppm}$ were prepared for the selected heavy metals: chromium $(\mathrm{Cr})$, cadmium $(\mathrm{Cd})$, zinc $(\mathrm{Zn})$, nickel $(\mathrm{Ni})$, lead $(\mathrm{Pb})$, and copper $(\mathrm{Cu})$.

\subsection{Chemical characterization and heavy metal analysis}

One hundred millilitres $(100 \mathrm{ml})$ of each sample was transferred into a digesting tube. Twelve millilitres $(12 \mathrm{ml})$ of a combined mixture of $\mathrm{HNO}_{3}$ and $\mathrm{HCl}$ in a ratio of $1: 3$ were added to the sample and heated on a hot plate inside a fume cupboard. The temperature was gradually raised, beginning at $50{ }^{\circ} \mathrm{C}$ and rising to $300{ }^{\circ} \mathrm{C}$. The digestion was completed in about 41 minutes, as indicated by the 
appearance of white fumes. The mixture was allowed to cool before being filtered into a 50-ml volumetric flask and filled with distilled water to the 50-ml mark. The filtrate was poured into a plastic bottle and labelled appropriately, after which a UNICAM atomic absorption spectrophotometer, model 969, was used to estimate the levels of the selected heavy metals.

The same spectrophotometer was used to determine the levels of phosphate, ammonia, sulphate, and nitrate in the samples, following the guidelines of Okezie et al. (2020).

\subsection{Microbial analysis}

The microbial load of each sample was determined as described by Palamuleni and Akoth (2015). Total bacteria was determined by plating out and filtering $0.1 \mathrm{ml}$ of the original water sample on nutrient agar plates and incubating it aerobically at $37{ }^{\circ} \mathrm{C}$ for 24 hours. At the end of incubation, the colonies that developed were counted using a colony counter. The coliform colonies were estimated by pouring the sample on Mac Conkey agar plates and incubating it at $37{ }^{\circ} \mathrm{C}$ for 24 hours. Fungi colonies were estimated the same way as the total bacteria, but the nutrient was supplemented with an antibiotic to prevent bacterial growth.

\subsection{Health risk evaluation}

The health risks of the wastewater were evaluated from the average oral exposure $(A O E)$ and average dermal exposure $(A D E)$ to the heavy metals in the samples using equations 1 and 2 (USEPA, 2004). The hazard quotient $(H Q)$ of the heavy metals via oral and dermal exposure was also estimated using equation 3 (USEPA, 2003).

$A O E=\frac{C O H \times \operatorname{Ir} \times E f \times E d}{A B W \times A t}$

According to Yahaya et al. (2020a), the full meaning and standard values of the variables in equation 1 are as follows: $A O E$ represents the average oral exposure per kilogram of body weight; $\mathrm{COH}$ indicates the concentration of heavy metals in water $(\mathrm{mg} / \mathrm{L})$; $I r$ shows the ingestion rate per unit time $(\mathrm{L} /$ day $)=2 ; E f$ is the exposure frequency (days/year) $=365 ; E d$ denotes the exposure duration (years) $=55$ (Nigerians' life expectancy); $A B W$ is the average body weight $(\mathrm{kg})=65 ; A t$ is the average time $(E d \times E f)=20075$.

$A D E=\frac{C O H \times \mathrm{SSA} \times D P C \times E t \times E f \times E d}{A B W \times A t}$

From Equation 2, $A D E$ is the average dermal exposure; $S S A$ is the skin surface area $\left(\mathrm{cm}^{3}\right)=28,000$; $D P C$ represents the dermal permeability constant $(\mathrm{cm} / \mathrm{h})$ of heavy metals: $\mathrm{Pb}=0.004, \mathrm{Ni}=0.0002$, $\mathrm{Cd}=0.001, \mathrm{Cr}=0.002, \mathrm{Zn}=0.006$, and $\mathrm{Cu}=0.001$. All of the other variables are as shown in Equation 1.

$H Q=\frac{\text { Exposure }(A O E \text { or } A D E)}{R F D}$

In Equation 3, $H Q$ represents the hazard quotient via oral or dermal contact (no units) and $R F D$ denotes the oral/dermal reference dose (mg/L/day). According to Yahaya et al. (2020a), RFD (oral and dermal) for $\mathrm{Pb}=1.4,0.42 ; \mathrm{Ni}=20,5.40 ; \mathrm{Cd}=0.5,0.005 ; \mathrm{Cr}=3.0,0.015 ; \mathrm{Zn}=0.3,0.3 ; \mathrm{Cu}=40$, 12.

\subsection{Data analysis}

Data were compiled as mean \pm standard deviation (SD) using the Excel software. 


\subsection{Results and Discussion}

\subsection{Chemical characteristics of the wastewater}

Table 1 shows the levels of the chemical characteristics of the wastewater samples collected from three eateries in Lekki, labeled Eatery A, B, and C. Sulphate was within the permissible limits of the Federal Environmental Protection Agency (FEPA) in all the eateries. However, nitrates, ammonia, and phosphate were above the limits. This result suggests that the wastewater may induce health and environmental hazards. Methemoglobinemia, birth abnormalities, malignancies, and thyroid disorders can all be caused by high levels of nitrate in drinking water or food (Ward et al., 2018; Yu et al., 2020). High ammonia exposure can cause burns to the eyes, nose, throat, and respiratory tract, as well as blindness and lupus (ATSDR, 2004). Phosphate overload can cause digestive problems (Kumar and Puri, 2012). Generally, phosphate, nitrate, and ammonia anions are acidic and, when absorbed in large amounts, they can cause an acid-base imbalance, resulting in more acidic conditions and acidiosis (Isiuku and Enyoh, 2020). Aquatic plant overgrowth can develop from high nitrate, ammonia, and phosphate ion concentrations in water bodies, resulting in algal blooms (Isiuku and Enyoh, 2020). This causes rapid dissolved oxygen depletion in the water, resulting in suffocation and the death of aquatic plants and animals. Decomposition of dead plants and animals degrades water quality. The results obtained under the current study are consistent with those of Ezigbo and Ezigbo (2020) and Gurd et al. (2020), who detected some chemical characteristics of water beyond recommended levels in fast-food wastewater.

Table 1: Chemical characteristics of wastewater obtained from selected eateries in Lekki, Lagos

\begin{tabular}{lcccc}
\hline Characteristics & Eatery A & Eatery B & Eatery C & Limit (FEPA, 1991) \\
\hline Nitrate & $21.287 \pm 2.32$ & $22.86 \pm 1.45$ & $24.32 \pm 2.61$ & $\leq 20$ \\
Ammonia & $16.337 \pm 1.21$ & $17.98 \pm 2.31$ & $17.64 \pm 2.02$ & $\leq 15$ \\
Sulphate & $5.847 \pm 0.006$ & $4.823 \pm 0.21$ & $4.980 \pm 0.010$ & $\leq 500$ \\
Phosphate & $14.870 \pm 0.010$ & $20.673 \pm 0.015$ & $14.970 \pm 0.010$ & $\leq 5.0$ \\
Values were expressed as Mean \pm SD and $m g / l ;$ FEPA $=$ Federal Environmental Protection Agency
\end{tabular}

\subsection{Levels of heavy metals in the wastewater and health risk}

The levels of $\mathrm{Cu}, \mathrm{Pb}, \mathrm{Ni}, \mathrm{Cd}, \mathrm{Cr}$, and $\mathrm{Zn}$ in the wastewater collected from the three eateries are revealed in Table 2 . With the exception of $\mathrm{Zn}$, the heavy metals were within the permissible limits of the FEPA in all the eateries. This result shows that the wastewater can induce $\mathrm{Zn}$ toxicity. Long-term, high-dose $\mathrm{Zn}$ may disrupt $\mathrm{Cu}$ uptake, predisposing to diseases associated with $\mathrm{Cu}$ deficiency (Plum et al., 2010). The result of the current study is in line with that of Ezigbo and Ezigbo (2020), who found abnormal levels of some heavy metals in wastewater from restaurants. Unfortunately, literature searches did not find more studies with the same objectives as the current study to which the current results can be compared.

Table 2: Levels of heavy metals in wastewater obtained from selected eateries in Lekki, Lagos

\begin{tabular}{|l|c|c|c|c|}
\hline Heavy metal & Eatery A & Eatery B & Eatery C & Limits (FEPA, 1991) \\
\hline $\mathrm{Cd}$ & BDL & BDL & BDL & $<1$ \\
\hline $\mathrm{Pb}$ & $0.022 \pm 0.002$ & $0.020 \pm 0.001$ & $0.080 \pm 0.002$ & $<1$ \\
\hline $\mathrm{Ni}$ & BDL & BDL & BDL & $<1$ \\
\hline $\mathrm{Cr}$ & $0.017 \pm 0.002$ & $0.025 \pm 0.003$ & $0.023 \pm 0.0005$ & $<1$ \\
\hline $\mathrm{Zn}$ & $2.746 \pm 0.002$ & $1.965 \pm 0.001$ & $1.444 \pm 0.003$ & $<1$ \\
\hline $\mathrm{Cu}$ & $0.326 \pm 0.007$ & $0.373 \pm 0.002$ & $0.285 \pm 0.0005$ & $<1$ \\
\hline
\end{tabular}

Values were expressed as Mean $\pm S D$ and $(m g / l) ; B D L=$ Below Detectable Limits; FEPA = Federal Environmental Protection Agency

Further analysis showed that the $A O E$ and $A D E$ to heavy metals in the wastewater were normal (Table 3). However, Table 4 shows that the $H Q$ of $\mathrm{Cr}$ and $\mathrm{Zn}$ via dermal exposure to wastewater from the three eateries was abnormal (>1). This again shows that residents are at an increased risk of $\mathrm{Zn}$ and $\mathrm{Cr}$ toxicities. When skin is exposed to high concentrations of $\mathrm{Zn}$, it develops lesions and slows wound healing, while $\mathrm{Cr}$ can induce dermatitis, skin cancer, or allergy (Plum et al., 2010; Jumina and Harizal, 2019). 
Table 3: Average daily oral and dermal exposure to heavy metals in wastewater obtained from selected eateries in Lekki, Lagos

\begin{tabular}{lccccccc}
\hline \multirow{2}{*}{ Heavy metal } & \multicolumn{2}{c}{ Eatery A } & \multicolumn{2}{c}{ Eatery B } & \multicolumn{2}{c}{ Eatery C } & Recommended \\
\cline { 2 - 6 } & Ingestion & Dermal & Ingestion & Dermal & Ingestion & Dermal & (WHO, 2017) \\
\hline $\mathrm{Cd}$ & - & - & - & - & - & - & 0.06 \\
$\mathrm{~Pb}$ & 0.001 & 0.038 & 0.001 & 0.009 & 0.0002 & 0.014 & 0.21 \\
$\mathrm{Ni}$ & - & - & - & - & - & - & 0.50 \\
$\mathrm{Cr}$ & 0.001 & 0.015 & 0.001 & 0.022 & 0.001 & 0.019 & 0.20 \\
$\mathrm{Zn}$ & 0.084 & 7.097 & 0.060 & 5.079 & 0.044 & 3.732 & 8.0 \\
$\mathrm{Cu}$ & 0.010 & 0.140 & 0.011 & 0.161 & 0.009 & 0.123 & 0.90 \\
\hline
\end{tabular}

Values were expressed in mg/day; $R D I=$ recommended daily intake

Table 4: Hazard quotient of heavy metals in the wastewater obtained from selected eateries in Lekki,

\begin{tabular}{lcccccc}
\multicolumn{7}{c}{ Lagos } \\
\hline Heavy metal & \multicolumn{2}{c}{ Eatery A } & \multicolumn{2}{c}{ Eatery B } & \multicolumn{2}{c}{ Eatery C } \\
\cline { 2 - 7 } & Ingestion & Dermal & Ingestion & Dermal & Ingestion & Dermal \\
\hline $\mathrm{Cd}$ & 0.00 & 0.08 & - & - & - & - \\
$\mathrm{Pb}$ & 0.00 & 0.09 & 0.00 & 0.00 & 0.00 & 0.03 \\
$\mathrm{Ni}$ & - & - & - & - & - & - \\
$\mathrm{Cr}$ & 0.00 & 1.00 & 0.00 & 1.47 & 0.00 & 1.27 \\
$\mathrm{Zn}$ & 0.28 & 23.66 & 0.20 & 16.93 & 0.15 & 12.44 \\
$\mathrm{Cu}$ & 0.00 & 0.01 & 0.00 & 0.01 & 0.01 & 0.01 \\
\hline
\end{tabular}

\subsection{Levels of microorganisms in the wastewater}

Table 5 reveals the levels of bacteria, coliform, and fungi in the wastewater samples. The total bacteria and fungi were detected above the FEPA permissible limits in all the eateries, while coliform was not detected. These microorganisms may contaminate food and public water supplies, causing waterborne diseases such as diarrhea, typhoid, cholera, giardia, salmonella, and hepatitis A, among others. The high microbial content of the wastewater might have been induced by its high nutrient content, particularly nitrate, ammonia, and phosphate. Wastewaters from eateries contain high organic matter and will require a high microbial load to boost degradation of solid wastes. The result of the current study is consistent with that of Ogidi and Oyetayo (2012), who isolated heavy microorganisms from restaurant wastewaters in Akure, Ondo State, Nigeria. The result is also in line with that of Usman et al. (2019), who detected high microbial species in some selected fast-food establishments in Kaduna, Nigeria.

Table 5: Levels of microorganisms in wastewater obtained from selected eateries in Lekki, Lagos

\begin{tabular}{lcccc}
\hline Microorganism & Eatery A & Eatery B & Eatery C & Limit (FEPA, 1991) \\
\hline Total bacteria & $1000 \pm 50.0$ & $800 \pm 100.0$ & $600 \pm 50.0$ & $\leq 100$ \\
Total coliform & ND & ND & ND & $<2.2$ \\
Total fungi & $1000 \pm 200$ & $1000 \leq 100.0$ & $1000 \pm 100.0$ & 0 \\
\hline
\end{tabular}

Values were expressed as Mean $\pm S D$ and CFU/ml; ND= Not Detected; FEPA = Federal Environmental Protection Agency

\subsection{Conclusions}

The results showed that wastewater obtained from three eateries in Lekki, Lagos, contained nonpermissible levels of some water parameters. The affected water parameters include nitrate, phosphate, ammonia, and zinc, as well as bacteria and fungi. The average daily oral and dermal exposure to the heavy metals was normal in all the eateries, but not so for the hazard quotient of daily dermal exposure to zinc and chromium. Overall, the results showed that the wastewater could pose health and environmental hazards if discharged into the environment untreated.

The following are suggested based on the results of the study:

- Owners of eateries should be compelled to treat wastewater before it is discharged into the drains.

- Residents should consider treating groundwater before consuming it if they are located close to an eatery's drains

- The surroundings of eateries should be kept clean and hygienic. 


\section{References}

Agency for Toxic Substances and Disease Registry (2004). ToxFAQs for Ammonia. Division of Toxicology, U.S. Department of Health and Human Services. Public Health Service: Atlanta, GA. Available at http://www.atsdr.cdc.gov/toxfaqs/tf.asp?id=10andtid=2 [Accessed May 6, 2021].

Aniyikaiye, E.T., T. O., John, O. O. and Joshua, N. E. (2019). Physico-Chemical Analysis of Wastewater Discharge from Selected Paint Industries in Lagos, Nigeria. International Journal of Environmental Research and Public Health, 16 (7), pp. 1235. https://doi.org/10.3390/ijerph16071235.

Bhargava, P., Gupta, N., Vats, S. and Goel, R. (2017). Health Issues and Heavy Metals. Austin Journal of Environmental Toxicology, 3(1), pp.1018. https://austinpublishinggroup.com/environmental-toxicology/fulltext/ajet-v3-id1018.pdf.

Chen, W., Li, Y., Chen, C. E., Sweetman, A. J. and Zhang, H., et al. (2017). DGT passive sampling for quantitative in situ measurements of compounds from household and personal care products in waters. Environmental Science and Technology, 51, pp.13274-13281. https://doi.org/10.1021/acs.est.7b03940

Du, P., Zhang, L., Ma, Y., Li, X., Wang, Z. and Mao, K., et al. (2020). Occurrence and Fate of Heavy Metals in Municipal Wastewater in Heilongjiang Province, China: Water, 12 (3), pp. 728. https://doi.org/10.3390/w12030728.

Ezigbo, V.O. and Ezigbo, C.I. (2020). Evaluation of Pysico-Chemical Contents of Waste Water (Effluents) from Fast Food Industries in Awka Anambra State. COOU Journal of Physical Sciences, 3(1), pp. 565-569. https://coou.edu.ng/journals/cjops/Vol3_Iss 1/cjps3120054.pdf.

Felicita, B. and Marija, V.D. (2017). Environmental microbiology. Physical Sciences Reviews, 2 (11), pp. 20160118. https://doi.org/10.1515/psr-2016-0118.

FEPA (1991). Interim guidelines and standards for industrial effluent, gaseous emissions and noise limitations. Nigeria: Federal environmental protection agency. Available at https://urbanlex.unhabitat.org/sites/default/files/faolex/interim_guidelines_and_standards_for _environmental_pollution_control_1991_0.pdf [Accessed January 27, 2022].

Gurd, C., Jefferson, B. and Villa, R. (2020). Characterisation of food service establishment wastewater and its implication for treatment. Journal of environmental management, 252, Article number 109657. DOI: 10.1016/j.jenvman.2019.109657.

Isiuku, B.O. and Enyoh, C.E. (2020). Pollution and health risks assessment of nitrate and phosphate concentrations in water bodies in South Eastern, Nigeria. Environmental Advances, 2, pp. 100018. https://doi.org/10.1016/j.envadv.2020.100018.

Jingxi, M., Shuqing, W., Ravi, S., Supriya, B. and Anoop, K.S. (2020). Determination of Physicochemical Parameters and Levels of Heavy Metals in Food Waste Water with Environmental Effects. Bioinorganic Chemistry and Applications, Article ID 8886093. https://doi.org/10.1155/2020/8886093.

Jumina, J. and Harizal, H. (2019). Dermatologic Toxicities and Biological Activities of Chromium, Trace Metals in the Environment - New Approaches and Recent Advances, Mario Alfonso MurilloTovar, Hugo Saldarriaga-Noreña and Agnieszka Saeid, IntechOpen, DOI: 10.5772/intechopen.90347.

Khedkar, R. and Singh, K. (2018). Food industry waste: A panacea or pollution hazard Springer International Publishing, Chapter 3, Pp. 35-47. https://www.springerprofessional.de/en/foodindustry-waste-a-panacea-or-pollution-hazard/13339394. 
Kumar, M. and Puri, A. (2012). A review of permissible limits of drinking water. Indian Journal of Occupational and Environmental Medicine, 16 (1), pp. 40-44. https://doi.org/10.4103/0019$\underline{5278.99696 .}$.

Macro, L.M. (2020). Defining how microorganisms benefit human health. Microbial Biotechnology, 14 (1), pp. 35-40. https://doi.org/10.1111/1751-7915.13685.

Ogidi, C. O. and Oyetayo, V. O. (2012). Assessment of Microbiological and Physiochemical properties of Wastewater from Restaurants in Akure, Nigeria. International Journal of Advanced Biological Research, 2(4), pp. 708-711.

Okezie, V.C., Odeke, E.H., Esew, O., Otori, M. and Idio, U.I. (2020). Physicochemical and Elemental Properties of the Discharged Wastewater from a Brewery Industry Located In Northwest Nigeria. International Journal of Engineering Science Invention (IJESI), 9 (2), pp. 9-16. http://www.ijesi.org/papers/Vol(9)i2/Series-1/B0902010916.pdf.

Okoh, A.T., Odjadjare, E.E., Igbinosa, E. O. and Osode, A.N. (2007). Wastewater treatment plants as a source of microbial pathogens in receiving water sheds. African Journal of Biotechnology, 6, pp. 2932-2944. https://doi.org/10.5897/AJB2007.000-2462.

Opadokun, I.O., Falaye, A.E. and Ajani E.K. (2015). Seasonal variations in physicochemical parameters of Lakki lagoon and the conservation of its ecosystem. Journal of Geoscience and Environmental Protection, 3, pp.11-17. http://dx.doi.org/10.4236/gep.2015.39002.

Palamuleni, L. and Akoth, M. (2015). Physico-Chemical and Microbial Analysis of Selected Borehole Water in Mahikeng, South Africa. International Journal of Environmental Research and Public Health, 12 (8), pp. 8619-8630. https://doi.org/10.3390/ijerph120808619.

Plum, L. M., Rink, L. and Haase, H. (2010). The essential toxin: impact of zinc on human health. International Journal of Environmental Research and Public Health, 7 (4), pp. 1342-1365. https://doi.org/10.3390/ijerph7041342.

Steffan, J.J., Brevik, E.C., Burgess, L.C. and Cerdà, A. (2018). The effect of soil on human health: an overview. European Journal of Soil Sciences, 69(1), pp.159-171. Doi: 10.1111/ejss.12451.

Turek, A., Wieczorek, K. and Wolf, W.M. (2019). Digestion Procedure and Determination of Heavy Metals in Sewage Sludge - an Analytical Problem. Sustainability, 11 (6), pp. 1753. https://doi.org/10.3390/su11061753.

Tytła, M. (2019). Assessment of Heavy Metal Pollution and Potential Ecological Risk in Sewage Sludge from Municipal Wastewater Treatment Plant Located in the Most Industrialized Region in Poland- Case Study. International Journal of Environmental Resources and Public Health, 16, pp. 2430. https://doi.org/10.3390/ijerph16132430.

United States Environmental Protection Agency (USEPA) (2003). Total dissolved solids in drinking water: background document for development of WHO Guidelines for drinking-water quality [Internet] Washington DC. Available from: http://www.who.int/water_sanitation_health/dwq/chemicals/tds.pdf. [Accessed October 19, 2021].

United States Environmental Protection Agency (USEPA) (2004) Risk assessment guidance for superfund (RAGS). Vol. 1, Human health evaluation manual [Internet] Washington, D.C. Supplemental guidance for dermal risk assessment. Available from: https://www.epa.gov/risk/riskassessment-guidance-superfund-rags-part-e. [Accessed October 19, 2021]. 
Usman, S., Afolabi, O.O. and Modupe, H.L. (2019). Evaluation of Microbial Load in Fast Food Establishments in Kaduna Metropolis. Journal of Community Medicine and Public Health Care, 6, pp. 042. DOI: 10.24966/CMPH-1978/100042.

Wang, W., Huang, L., Zhu, Y., Jiang, L. and Sahu, A.K., et al. (2020). Decision support system toward evaluation of resilient supplier: A novel fuzzy gain-loss computational approach. Kybernetes, 49 (6), pp. 1741-1765. https://doi.org/10.1108/K-05-2019-0345.

Ward, M.H., Jones, R.R., Brender, J.D., de Kok, T.M. and Weyer, P. J., et al. (2018). Drinking Water Nitrate and Human Health: An Updated Review. International Journal of Environmental Research and Public Health, 15(7), pp.1557. https://doi.org/10.3390/ijerph15071557.

World Health Organization (WHO) (2017). Guidelines for drinking-water quality. Fourth edition incorporating the first addendum, Pp. 1-631.

World Health Organization (WHO) (2020). Food Safety. https://www.who.int/news-room/factsheets/detail/food-safety [Accessed October 19, 2021].

Wu, K., Chang, C., Yen, C. and Lai, C. (2019). Associations between environmental heavy metal exposure and childhood asthma: A population-based study. Journal of Microbiology, Immunology and Infection, 52 (2), pp. 352-362. https://doi.org/10.1016/j.jmii.2018.08.001.

Yahaya, T., Doherty, V.F., Akinola, O.S. and Shamsudeen, A. (2019). Heavy metal profiles and microbial counts of selected sachet water brands in Birnin Kebbi Metropolis, Nigeria. Ife Journal of Science, 21 (1), pp. 229-234. https://doi.org/10.4314/ijs.v21i1.20.

Yahaya, T. and Okpuzor, J. (2011). Variation in Exposure to Cement Dust in Relation to Distance from Cement Company. Research Journal of Environmental Toxicology, 5, pp. 203212. DOI: 10.3923/rjet.2011.203.212.

Yahaya, T. and Okpuzor, J. (2012). Investigation of Cytotoxicity and Mutagenicity of Cement dust Using Allium Cepa Test. Research Journal of Mutagenesis, 2 (1), pp. 10-18. http://dx.doi.org/10.3923/rjmutag.2012.10.18.

Yahaya, T., Oladele, E., Fatodu, I., Abdulazeez, A. and Yeldu, Y. (2020a). The Concentration and Health Risk Evaluation of Heavy Metals and Microorganisms in Groundwater in Lagos, Southwest Nigeria. Journal of Advances in Environmental Health Research, 8 (3), pp. 234242.10.22102/jaehr.2020.245629.1183.

Yahaya, T., Oladele, E., Chibs, B., Abdulazeez, A. and Nnochiria, K., et al. (2020b). Level and Health Risk Evaluation of Heavy Metals and Microorganisms in Urban Soils of Lagos, Southwest Nigeria. Algerian Journal of Biosciences, 1(2), pp. 051-060. DOI: http://dx.doi.org/10.5281/zenodo.4394091.

Yu, G., Wang, J. and Liu, L. (2020). The analysis of groundwater nitrate pollution and health risk assessment in rural areas of Yantai, China. BMC Public Health, 20, pp. 437. https://doi.org/10.1186/s12889-020-08583-y.

\footnotetext{
Cite this article as:

Tajudeen Y., Abdulganiyu Y., Alkali M., Ukpere M., Ayodeji S. O., Ahmadu A. I. and Faluyi B. A., 2022. Occurrence and Health Risk of Heavy Metals and Microorganisms in Wastewater Collected from selected Eateries in Lekki, Lagos, Nigeria. Nigerian Journal of Environmental Sciences and Technology, 6(1), pp. 38-46. https://doi.org/10.36263/nijest.2022.01.0316
} 